\title{
Note
}

\section{CONSTITUTIONAL RESTRICTIONS ON HUMAN RIGHTS AND FREEDOMS IN THE DEVELOPMENT OF LIBERAL DEMOCRACY IN EUROPE}

\author{
Nataliia Plakhotniuk, Uliana Koruts and Elmira Doroshenko
}

Summary: 1. Introduction. -2 . Derogations of Human Rights under the British Constitutional Model. -3 . Restrictions of Human Rights in Continental Europe. - 4. Legal Scope of Restrictions in Eastern Europe. - 5. Peculiarities of Human Rights Restrictions in Balkan Countries. - 6. Restrictions of Human Rights in Baltic States. - 7. The Scandinavian Model of Exceptions to Ensure Constitutional Human Rights. - 8. Conclusion

To cite this note: N Plakhotniuk, U Koruts and E Doroshenko, 'Constitutional Restriction on Human Rights and Freedoms in the Development of Liberal Democracy in Europe' 2021 3(11) Access to Justice in Eastern Europe 129-143. D0l: https://doi.org/10.33327/AJEE-18-4.3-n000075

To link to this note: https://doi.org/10.33327/AJEE-18-4.3-n000075

Submitted on 01 May 2021 / Revised 20 May 2021 / Revised 24 Jun 2021 / Approved 26 Jul 2021 / Published online: 02 Aug $2021 \quad$ View data

Submit your article to Access to Justice in Eastern Europe

\section{ACKNOWLEDGEMENTS}

The authors would like to express their gratitude to the reviewers and editors of the Journal for their help and to the English editor, Sarah White.

\section{CONFLICTS OF INTEREST}

The authors declare no conflict of interest of relevance to this topic.

\section{CONTRIBUTORSHIP}

The authors are equally contributed to the intellectual discussion underlying this paper, writing, and accept responsibility for the content and interpretation. 


\title{
CONSTITUTIONAL RESTRICTIONS ON HUMAN RIGHTS AND FREEDOMS IN THE DEVELOPMENT OF LIBERAL DEMOCRACY IN EUROPE
}

\author{
Plakhotniuk Nataliia \\ PhD (Law), Associate Professor, Head of State Sciences and Law Department \\ of the National Academy of Public Administration under the President of Ukraine \\ nat pl@ua.fm \\ https://orcid.org/0000-0002-8442-1149
}

\section{Koruts Uliana}

PhD (Law), Associate Professor, Head of International Office of West Ukrainian National University

u.koruts@wunu.edu.ua

https://orcid.org/0000-0001-6999-8532

\section{Doroshenko Elmira}

Postgraduate Student of the National Academy on Public Administration under the President of Ukraine.

elmira.doroshenkoo@gmail.com

\section{A}

bstract This article is dedicated to the constitutional restrictions on human rights and freedoms within the genesis and development of liberal democracy.

The article argues that European countries implement the provisions of the ECHR in various ways regarding the application of restrictions of rights and freedoms in their own national legal systems in order to support: 1) the state and public security or economic well-being of the country; 2) the prevention of riots or crimes; 3) health or morals or for the purpose of protecting the rights and freedoms of others; 4) the protection of national security or territorial integrity; 5) protecting the reputation of others; 6) the prevention of disclosure of confidential information; 7) maintaining the authority and impartiality of judicial authorities.

The research defines a common feature of all constitutional restrictions of human rights and freedoms within the European countries'application, taking into account the objective circumstances necessary in a democratic society. The authors underline that under no circumstances should the restrictions distort the essence of human rights and freedoms that fall under such derogations.

The article underlines that the restrictions on human rights and freedoms are a necessary component of the legal system of any state and modern society. Such restrictions should be of a legal nature and should be imposed only in accordance with the general interest - national security, law and order, the protection of moral norms, and the protection of the rights and freedoms of other persons when the right of another person in a legitimate balance prevails. The emergence of challenges to human rights does not negate their effectiveness, and they continue to operate, which testifies to their effectiveness and guarantees the inviolability of the rule of law principle when resolving specific cases on human rights restrictions.

Keywords: rule of law, constitutional restrictions, constitutional control, human rights, fundamental freedoms, access to justice, European Court of Human Rights, national legislation, legal scope, judicial system. 


\section{INTRODUCTION}

Nowadays, the majority of democratic systems in Europe arose under the influence of liberalism. Liberalism has always been associated with individual freedom and protection from state tyranny. Liberal democracy has been a significant step towards respecting human dignity. The modern democracy of many European countries follows the main principles of a liberal political system: constitutionalism, the separation of powers, and values such as individual freedom, human rights, minority autonomy, etc.

At the same time, the ensuring of principles and values requires states to impose certain restrictions to guarantee sovereignty, public order, the protection of the health of their own citizens, and the common welfare.

Regarding the scientific constitutional doctrine of Ukraine, for instance, M. Savchyn revealed the content of the criteria for limiting human rights, indicating that the systematic nature of human rights causes the value-based independent determination of permissible restrictions of fundamental rights, which should be tied to specific circumstances and urgent needs in a democratic society. In conformity with this author, the requirement for a democratic structure of society determines certain standards in establishing criteria for human rights restrictions that should correspond to urgent social needs. ${ }^{1}$

To ensure the democratic structure of states and fundamental human rights and freedoms, the European countries formed the Council of Europe in 1949.

With the establishment of the Council of Europe, this international organisation faced the need to adopt a legally binding document, that is, an international treaty that would fix the fundamental human rights and freedoms at the European level. This situation is explained by the fact that from the very beginning of its creation, the Council of Europe considered it necessary to act as an international organisation serving as a comprehensive standard for the protection of human rights, regardless of certain circumstances (peaceful or martial law) over the following centuries. ${ }^{2}$

Therefore, on 4 November 1950, the governments of Western European countries adopted the Convention for the Protection of Human Rights and Fundamental Freedoms (hereinafter, ECHR). ${ }^{3}$ The document became the first international human rights document that not only declares human rights and calls for their observance but also imposes certain legal obligations on the parties and introduces a system of control over the exercise and observance of human rights in the Council of Europe member states. ${ }^{4}$ The approach introduced by the General Declaration and the European Convention is unique - whatever the law of the member states, everyone is guaranteed the rights enshrined in these documents. These are rights that unite all people, not ones that divide national and ethnic attitudes and traditions. ${ }^{5}$

$1 \quad$ M Savchyn, Current Trends in Constitutionalism in the Context of Globalization and Legal Pluralism: Monograph (RICK-U 2018) 123-124.

2 V Muraviov V, N Mushak, 'Legal Issues of the Implementation of the Convention for the protection of Human Rights and Fundamental Freedoms 1950 in Ukraine’ (2021) 1 (9) Access to Justice in Eastern Europe 11-22.

3 Council of Europe, Convention for the Protection of Human Rights and Fundamental Freedoms [1950] $<$ https://www.echr.coe.int/documents/convention_eng.pdf> accessed 20 May 2021.

4 M Muraviov, N Mushak, 'Judicial Control of Public Power as Legal Instrument for Protection of Human Rights and Fundamental Freedoms in Ukraine' in Rule of Law, Human Rights and Judicial Control of Power (Springer 2017).

5 I Izarova, S Kravtsov, 'About the Special Issue on the Occasion of the 70th Anniversary of the European Convention on Human Rights' (2021) 1 (9) Access to Justice in Eastern Europe 5-7. 
At the same time, the issues of application by the ECHR member states of a number of restrictions on fundamental human rights and freedoms are almost entirely investigated in both foreign and domestic doctrines on constitutional law. ${ }^{6}$ We would like to emphasise that the ECHR is not only the foundation of the whole complex of international legal regulation in the field of human rights, its legitimate interests, and needs but also acts as a guideline for its member states, thereby defining a clear framework for the application of restrictions on such rights. In particular, in accordance with Art. 18 of the ECHR, the restrictions permitted under this Convention shall not apply for purposes other than those for which they are established. ${ }^{7}$

In addition, within the ECHR, we can see that the objectives of limitations of human rights in comparison with the Universal Declaration of Human Rights $1948^{8}$ and the International Covenant on Political and Civil Rights $1966^{\circ}$ were significantly expanded and introduced to support: 1) the state and public security or economic well-being of the country; 2) the prevention of riots or crimes; 3 ) health or morals or for the purpose of protecting the rights and freedoms of others; 4) protection of national security or territorial integrity; 5) protecting the reputation of others; 6) the prevention of disclosure of confidential information; 7) maintaining the authority and impartiality of judicial authorities. ${ }^{10}$

\section{DEROGATIONS OF HUMAN RIGHTS UNDER THE BRITISH CONSTITUTIONAL MODEL}

The issue of restrictions on human rights and freedoms enshrined in the ECHR is most comprehensively implemented in the United Kingdom, which is one of the ten founding countries of the Council of Europe.

It should be noted, of course, that in British law, there is no single classification of the rights and freedoms of citizens. As a rule, rights and freedoms are primarily individual rights that may be limited by the state by virtue of a contract. This means that everyone can do things that are not expressly prohibited by law.

In addition, when studying human rights and fundamental freedoms in the UK, the specifics of the country's legal system should also be taken into account since international conventions on its territory are not directly valid. That is, persons in the territory of this country cannot directly refer to international legal acts in terms of ensuring their rights and fundamental freedoms, with the exception of the Convention for the Protection of Human Rights and Fundamental Freedoms of 1950, for which the Human Rights Act of 1998 (hereinafter, Act) was adopted in the UK. ${ }^{11}$

In accordance with this Act, the provisions of Art. 1-12 and Art. 14 of the Convention, Art. 1-3 of Protocol No. 1 and Art. 1-2 of Protocol No. 6 to the Convention were implemented

$6 \quad$ N Siskova, 'European Union's Legal Instruments to Strengthen the Rule of Law? Their Actual Reflections and Future Prospects' in N Šišková (ed), The European Union - What Is Next? A Legal Analysis and the Political Visions on the Future of the Union (Wolters Kluwer 2018) 157-162.

7 B Sydorets, 'Restrictions on Human Rights (in the context of the ratio of the Constitution of Ukraine and the Convention for the Protection of Human Rights and Fundamental Freedoms)' (2012) 1 Elections and Democracy 63-69.

8 Universal Declaration of Human Rights [1948] <https://www.un.org/en/about-us/universaldeclaration-of-human-rights> accessed 20 May 2021.

9 International Covenant on Civil and Political Rights [1966] <https://www.ohchr.org/en/ professionalinterest/pages/ccpr.aspx> accessed 20 May 2021.

$10 \mathrm{R}$ Arnold, 'Anthropocentric Constitutionalism in the European Union: Some Reflections' in The European Union - What Is Next? (Wolters Kluwer 2018) 112-13.

11 Human Rights Act [1998] <www.legislation.gov.uk/ukpga/1998/42> accessed 20 May 2021. 
into the national legislation. Also, it provides for the duties of state bodies that are obliged to ensure the relevant rights.

The mechanism of implementation for the Act was built on a classic British constitutional model with the modernisation of new approaches. ${ }^{12}$ The ECHR was incorporated into the legal system of the UK without the establishment of a special regime for the application of Convention law by British courts. It should be noted that incorporation did not provide the Convention with the status of fundamental norms that human rights have in the legal systems of other states, such as the Czech Republic, Germany, Poland, etc.

According to Art. 10 of the Act, everyone has the right to freedom of expression. This right includes the freedom to think, receive, and transmit information and ideas without interference by the state authorities and regardless of borders. At the same time, subpara. 2 of the same article states that the exercise of these freedoms may be subject to such formalities, conditions, restrictions, or punishments that are provided for by law and are necessary for a democratic society, in the interests of national security, territorial disorder, or for the protection of the health, morality, reputation, or rights of others, to prevent the disclosure of information obtained in secret, or to preserve the authority and impartiality of the judiciary.

This provision was reinforced by the ECHR's judicial practice in The Observer and The Guardian v. the United Kingdom. ${ }^{13}$

The point of the case was that The Guardian and The Observer newspapers published excerpts from Peter Wright's book 'The Spy Catcher', which contained allegations that MI5 acted unlawfully.

The UK government received a court order prohibiting newspapers from printing additional further materials until the secrecy proceedings are over. But when the book was published, The Guardian complained that the continuation of the court order violated the right to freedom of speech. In this regard, the ECtHR ruled that the court order was legal because it was fully in the interests of national security. However, the ECtHR also noted that this was not enough to continue the ban on the publication of newspapers after the publication of the book since the information is still not confidential. Compared to the UK, in continental Europe, in particular, Germany and Spain, at the level of the constitutions of both countries, there are significantly more constitutional restrictions on human rights and freedoms, which can only be applied by law.

\section{RESTRICTIONS OF HUMAN RIGHTS IN CONTINENTAL EUROPE}

In Germany, at the level of the Constitution of 23 May 1949, a number of constitutional restrictions on human rights and freedoms were established. ${ }^{14}$ For instance, Art. 8 regulates that the right of German citizens to peaceful assembly without prior application or permit restriction can be imposed only by law or on the basis of law. The same conditions are

12 AL Young, P Birkinshaw, V Mitsilegas, TA Christou, 'Europe's Gift to the United Kingdom's Unwritten Constitution - Juridification' in A Albi, S Bardutzky (eds) National Constitutions in European and Global Governance: Democracy, Rights, the Rule of Law (TMC Asser Press 2019) <https://doi.org/10.1007/978-94-6265-273-6_3> accessed 24 June 2021.

13 S Coliver, 'Spycatcher - The Legal and Broader Significance of the European Court's Judgment' (1992) 142 Tolley's J Media L \& Prac <https://heinonline.org/HOL/LandingPage?handle=hein.journals/ tojmedlp13\&div=8\&id=\&page $>$ accessed 20 May 2021 .

14 Basic Law for the Federal Republic of Germany of 23 May $1949<$ https://www.btg-bestellservice.de/ pdf/80201000.pdf> accessed 20 May 2021. 
provided for in Art. 10 on ensuring the secrecy of correspondence, along with the secrecy of postal and teleconference. That is, restrictions can be established only on the basis of the law. This law may establish that such restrictions are not reported to the interested person if they are aimed at the protection of the foundations of a free democratic system or the existence or preservation of the Federation or any land. The judicial procedure is replaced by the verification by special and auxiliary bodies appointed by the people's representative office.

The following article of the German Basic Law states that all Germans enjoy the freedom of movement throughout the federal territory (Art. 11). At the same time, this right may be limited by law or on the basis of the law and only in cases where there are no sufficient funds for its implementation, as a result of which there would be special difficulties for society. Another case is when such restrictions are necessary to prevent danger that threatens the foundations of the free democratic order of the Federation or any land or their existence, or when they are necessary to combat the danger of epidemics, to take measures against natural disasters or especially serious accidents, or to protect young people from carelessness or to prevent criminal acts. ${ }^{15}$

Some cases of human rights restrictions relate to housing integrity. Such situations may take place only to prevent public danger or danger to the lives of individuals, as well as on the basis of law to prevent an immediate threat to public safety and order, in particular, to eliminate the need for housing, combat epidemics, or protect young people from future danger.

In general, when analysing those provisions of the German Constitution that directly relate to restrictions on human rights, it can be noted that human rights can be limited only by law or on the basis of law. ${ }^{16}$ Moreover, this law should be general in nature and not be applied to a separate case.

The Spanish Constitution of 27 December 1978, for example, in Art. 16, guarantees the freedom of ideology, religion, and worship of individuals and communities with no restrictions on their expression. ${ }^{17}$ At the same time, restrictions may be applied that are necessary to maintain public order as protected by law. These rules also apply to obtaining information by any means (Art. 20). The Law regulates the use of this right, taking into account the restrictions imposed by the requirements of morality and the preservation of professional secrecy during the exercise of these rights. ${ }^{18}$

At the same time, the Basic Law of Spain stipulates that the right to free choice of place of residence and movement within its territory and the right of free entry/exit to and from Spain cannot be limited for political or ideological reasons (Art. 19). ${ }^{19}$ The Spanish Basic Law does not provide for restrictions on human rights and freedoms in a broad sense.

15 M Savchyn, 'Basic Constitutional Criteria for Limitation of Human Rights and Fundamental Freedoms' (2008) 2 (16) Elections and Democracy 21-28.

16 K Lachmayer, 'The Constitution of Austria in International Constitutional Networks: Pluralism, Dialogues and Diversity' in A Albi, S Bardutzky (eds), National Constitutions in European and Global Governance: Democracy, Rights, the Rule of Law (TMC Asser Press 2019) <https://doi. org/10.1007/978-94-6265-273-6_27> accessed 24 June 2021.

17 Constitution of Spain, 27 December $1978<$ https://www.constituteproject.org/constitution/Spain_2011. pdf?lang=en $>$ accessed 24 June 2021.

18 J Solanes Mullor, ATorres Pérez, 'The Constitution of Spain: The Challenges for the Constitutional Order Under European and Global Governance' in A Albi, S Bardutzky (eds) National Constitutions in European and Global Governance: Democracy, Rights, the Rule of Law (TMC Asser Press 2019) <https://doi.org/10.1007/978-94-6265-273-6_12> accessed 24 June 2021.

19 U Mussig, 'A New Order of the Ages. Normativity and Precedence' in U Mussig (ed), Reconsidering Constitutional Formation II Decisive Constitutional Normativity. Studies in the History of Law and Justice, vol 12 (Springer 2018) <https://doi.org/10.1007/978-3-319-73037-0_1> accessed 24 June 2021. 
These restrictions set up in the constitutions of Spain and Germany reflect the main approaches to the formulation of human rights restrictions of countries of Western Europe.

\section{LEGAL SCOPE OF RESTRICTIONS IN EASTERN EUROPE}

Unlike the countries of Western Europe, in Eastern Europe, particularly in Poland and the Czech Republic, a clear scope of restrictions on freedoms and human and citizens' rights during periods of martial law and exceptional status, as well as during periods of natural disasters, is fixed at the constitutional level. Compared to the Basic Law of Germany, the Constitution of Poland defines the legal norms governing restrictions on the use of constitutional freedoms and rights in a broader sense. In particular, such restrictions may be established only by law and only if they are necessary in a democratic state for its safety or for the provision of public order, for the protection of the environment, health, and public morality, or the freedoms and rights of others (Art. 31) ${ }^{20}$ In addition, such restrictions cannot contradict the essence of freedoms and rights.

At the same time, like the German Constitution, the Basic Law of Poland provides for certain constitutional restrictions on human freedoms regarding personal inviolability (Art. 41), freedom and protection of the secrecy of correspondence (Art. 49), the right of access to official documents and data banks relating to it (Art. 51), and freedom of organisation of peaceful assembly and participation in such assemblies (Art. 57) in accordance with the principles and in the order defined by law.

It is important that the Constitution of Poland enshrines a clear scope of restrictions on freedoms and human and citizen rights during periods of martial law, exceptional status, or natural disaster. ${ }^{21}$ For instance, in periods of martial law or exceptional condition, Art. 233 stipulates that it cannot restrict the freedoms and rights defined in Art. 30 (human dignity), Art. 34 and Art. 36 (citizenship), Art. 38 (protection of life), Art. 39, Art. 40 and Part 4 of Article 41 (human treatment), Art. 42 (criminal liability), Art. 45 (access to court), Art. 53 (conscience and religion), Art. 63 (petition), and Art. 48 and Art. 72 (family and child).

In turn, during periods of natural disaster, it is possible to limit the freedoms and rights established in Art. 22 (freedom of economic activity), parts 1, 3, and 5 of Art. 41 (personal freedom), Art. 50 (inviolability of housing), part 1 Art. 52 (freedom of movement and stay in the territory of the Polish Republic), part 3 Art. 59 (right to strike), Art. 64 (right of ownership), part 1 of Art. 66 (right to safe and healthy working conditions), part 1 of Art. 65 (freedom of work), and part 2 of Art. 66 (right to rest).

This does not assume restriction of freedoms and rights of a person and a citizen depending solely on race, gender, language, religion or lack thereof, social origin, birth, or property status. In our opinion, compared to a number of European countries we have already analysed, a more complete consolidation of restrictions not only on personal but political and economic human rights is contained in the Constitution of the Czech Republic of 1992.22 The document states that legal restrictions on fundamental rights and freedoms must

20 Constitution of the Republic of Poland of 2 April $1997<$ https://www.sejm.gov.pl/prawo/konst/ angielski/kon 1.htm> accessed 20 May 2021.

21 S Biernat, M Kawczyńska, 'The Role of the Polish Constitution (Pre-2016): Development of a Liberal Democracy in the European and International Context' in A Albi, S Bardutzky (eds), National Constitutions in European and Global Governance: Democracy, Rights, the Rule of Law (TMC Asser Press 2019) <https://doi.org/10.1007/978-94-6265-273-6_16> accessed 24 June 2021.

22 Constitution of the Czech Republic of 16 December $1992<$ https://www.psp.cz/en/docs/laws/1993/1. html > accessed 20 May 2021. 
act equally in all cases that meet the specific conditions. When applying norms on the limits of the realisation of fundamental rights and freedoms, their essence and meaning should be taken into account. In addition, restrictions on rights can be carried out only for the purposes for which they are established.

Thus, according to Art. 7, the inviolability of the person and his/her privacy is guaranteed. Restrictions are allowed only in cases established by law. The same rules are applied to restrictions on ownership, which is allowed only in the public interest, on the basis of law, and subject to proper reimbursement.

As in most European countries, freedom of movement and residence is guaranteed. However, if it is necessary for the safety of the state, to maintain public order, for health care, to protect the rights and freedoms of others, or for the purposes of protecting nature, then these freedoms may also be limited by law.

In comparison with the Constitutions of Germany, Poland, Croatia, Lithuania, and Estonia, the Basic Law of the Czech Republic clearly distinguishes between restrictions in political rights on the one hand and economic, social, and cultural rights on the other. Thus, we believe that the Constitution of the Czech Republic most fully reflects the restrictions on the rights and freedoms of persons defined in international documents. Here, we are speaking about the International Covenant on Civil and Political Rights 1966 and the International Covenant on Economic, Social and Cultural Rights 1966.

In particular, the restrictions of political rights are established (Art. 17), along with freedom of speech and the right to information. These restrictions are defined by law and are necessary for a democratic society to protect the rights and freedoms of others, the security of the state, public safety, health, and morality. As for another right, namely, the right to peaceful assembly, it may be limited by law in cases of holding meetings in public places, if such measures are necessary in a democratic society to protect the rights and freedoms of others, public order, health and morals, property, or to ensure the safety of the state. The right to gather cannot be conditioned by the permission of a public administration body.

The right to unions, which is enshrined in Art. 20 of the Czech Constitution, may be limited only in cases established by law if it is necessary to ensure the security of the state, protect public safety and order, prevent crimes, or protect the rights and freedoms of others in a democratic society.

A separate section of the document is devoted to restrictions on economic, social, and cultural rights. Thus, taking into account the fact that everyone has the right to free choice of profession and preparation for it, as well as the right to engage in entrepreneurial, economic, and other activities, the law may set conditions and restrictions for the implementation of certain professions or activities. This is provided in Art. 26 of the Basic Law of the Czech Republic. ${ }^{23}$

The Constitution of the Czech Republic and Poland can be used as examples of the constitutional development of countries of Eastern Europe whose constitutions were modified in the 90 s as a result of the countries' integration into the European Union.

23 N Mohammad, SM Hasan, 'Human Rights' in D Crowther, S Seifi (eds), The Palgrave Handbook of Corporate Social Responsibility (Palgrave Macmillan 2020) <https://doi.org/10.1007/978-3-03022438-7_22-1> accessed 24 June 2021. 


\section{PECULIARITIES OF HUMAN RIGHTS RESTRICTIONS IN BALKAN COUNTRIES}

The main peculiarities of Balkan countries' constitutions arise from the fact that these countries became independent after the disintegration of the former Socialist Republic of Yugoslavia.

In Balkan countries, for example, in Croatia and Montenegro, the types of restrictions on human rights can be traced like those in Germany and Poland.

According to the Croatian Constitution, the freedom and rights of citizens may be limited only by law in order to protect the freedoms and rights of others, as well as law and order, public morality, and health (Art. 16). ${ }^{24}$ In each case, any restriction of freedoms or rights must correspond to the nature of the need to limit them. ${ }^{25}$

The Constitution of Croatia establishes the scope and conditions of application by the state of a number of restrictions (Art.17). ${ }^{26}$ In particular, certain freedoms and rights of citizens guaranteed by the Constitution may be restricted during martial law or in cases of direct threats to the independence and unity of the state, as well as during significant natural disasters. The decision to restrict the rights and freedoms of citizens is taken by Croatian Parliament (Sabor) by a majority of two-thirds of the total number of deputies. If Sabor cannot be convened at the suggestion of the Government and in the presence of a counter-assembly of the Head of Government, then the decision is made by the President of the Republic.

The scope of restrictions must correspond to the nature of the danger, and the measures taken should not lead to inequality of citizens depending on race, skin colour, gender, language, religion, or national and social origin. Even in cases of immediate danger to the existence of the state, the application of the provisions of this Constitution on the right to life, prohibition of torture, cruel or degrading treatment or punishment, the need for legal justification of criminally punishable acts and punishments, as well as provisions on freedom of thought, conscience, and religion cannot be limited.

A set of restrictions under the Basic Law of Croatia can be applied both on the basis of law and by a court decision on human freedom (Art. 22), the right to free association in order to protect their interests or to express social, economic, political, national, cultural or other beliefs and purposes (Art. 43). The right to freedom of association is restricted by a ban on violence against a democratic constitutional order, as well as the independence, unity, and territorial integrity of the Republic of Croatia.

Restrictions also apply to freedom of movement and choice of place of residence (Art. 32). Thus, the right to move within the territory of the Republic of Croatia and the right of entry or exit abroad may be limited by law in exceptional cases if it is necessary to protect the law and order or health, rights, and freedoms of other citizens.

In turn, the Basic Law of Montenegro establishes the same restrictions on human rights and freedoms as Croatia. It should be noted that only 4 articles of the Constitution of Montenegro

24 Constitution of the Republic of Croatia of 22 December $1990<$ https://www.usud.hr/sites/default/files/ dokumenti/The_consolidated_text_of_the_Constitution_of_the_Republic_of_Croatia_as_of_15_ January_2014.pdf $>$ accessed 20 May 2021 .

25 I Goldner Lang, Z Đurđević, M Mataija, 'The Constitution of Croatia in the Perspective of European and Global Governance' in A Albi, S Bardutzky (eds), National Constitutions in European and Global Governance: Democracy, Rights, the Rule of Law (TMC Asser Press 2019) <https://doi. org/10.1007/978-94-6265-273-6_24> accessed 24 June 2021.

26 B Kostadinov, 'Human Dignity in Croatia' in P Becchi, K Mathis (eds), Handbook of Human Dignity in Europe (Springer 2018) <https://doi.org/10.1007/978-3-319-27830-8_7-1> accessed 24 June 2021. 
contain a list of restrictions on human rights and freedoms. ${ }^{27}$ Such restrictions concern the freedom of movement and residence of persons (Art. 39), freedom of expression (Art. 46), the right to freedom of assembly (Art. 52), and the right to property (Art. 58). ${ }^{28}$

In particular, freedom of movement, residence, and departure from Montenegro may be restricted if required for criminal proceedings, prevention of the spread of infectious diseases or for security reasons in Montenegro. Freedom of thought, conscience, and religion (Art. 46) may be restricted only if it requires the protection of people's lives and health, public order, and other rights guaranteed by the Constitution.

The right of persons to freedom of assembly (Art. 52) may be temporarily limited by the decision of the competent authority in order to prevent disorder or execution of a criminal offence or a threat to health, morality, or safety of people or property in accordance with the law. The right to property (Art. 58) by the Constitution of Montenegro is limited solely in the public interest with equivalent compensation.

\section{RESTRICTIONS OF HUMAN RIGHTS IN BALTIC STATES}

In the Baltic states, in particular Lithuania, in Art. 26 'Freedom of thought, religion and conscience, a person's freedom to profess and spread religion or faith cannot be limited otherwise, as only by law and only if it is necessary to guarantee public safety, public order, health and morality of people, as well as the fundamental rights and freedoms of other persons. ${ }^{29}$

Restrictions on human rights and granting privileges depending on a person's gender, race, nationality, language, origin, social status, religion, beliefs, or views are not allowed (Art. 29).

In addition, unlike in a number of the European countries that have already been analysed, the Basic Law of Lithuania also provides for the introduction of restrictions within the framework of social and economic rights. We are talking about the right of workers to strike (Art. 51).$^{30}$ It should be noted that the restrictions, conditions, and procedure for exercising this right are established by law.

The provisions enshrined in the Constitution of Estonia are like those of the Constitution of Lithuania. In particular, the document states that rights and freedoms may be limited only in accordance with the Constitution (Art. 11). ${ }^{31}$ Such restrictions should be necessary for a democratic society and should not distort the essence of human rights and freedoms that are limited. ${ }^{32}$

27 D Franeta, 'Human Dignity in Montenegro' in P Becchi, K Mathis (eds), Handbook of Human Dignity in Europe (Springer 2019) <https://doi.org/10.1007/978-3-319-28082-0_29> accessed 24 June 2021.

28 Constitution of Montenegro, 25 October $2007<$ https://www.wipo.int/edocs/lexdocs/laws/en/me/ me004en.pdf> accessed 20 May 2021.

29 Constitution of the Republic of Lithuania, 25 October $1992<$ https://e-seimas.lrs.lt/portal/legalAct/lt/ TAD/TAIS.21892?jfwid=-wd7z8ivg5> accessed 20 May 2021.

30 I Jarukaitis, G Švedas, 'The Constitutional Experience of Lithuania in the Context of European and Global Governance Challenges’ in A Albi, S Bardutzky (eds), National Constitutions in European and Global Governance: Democracy, Rights, the Rule of Law (TMC Asser Press 2019) <https://doi. org/10.1007/978-94-6265-273-6_21> accessed 24 June 2021.

31 Constitution of the Republic of Estonia, 28 June $1992<$ https://www.constituteproject.org/constitution/ Estonia_2015.pdf?lang=en> accessed 20 May 2021.

32 M Ernits et al, 'The Constitution of Estonia: The Unexpected Challenges of Unlimited Primacy of EU Law' in A Albi, S Bardutzky (eds), National Constitutions in European and Global Governance: Democracy, Rights, the Rule of Law (TMC Asser Press 2019) <https://doi.org/10.1007/978-94-6265273-6_19> accessed 24 June 2021. 
According to the Basic Law of Estonia, restrictions may also apply to human rights to property (Art. 32), freedom of movement and residence (Art. 34), the right of a person to receive information (Art. 44), freedom of expression (Art. 45), and the right to peaceful assembly (Art. 47).

For example, according to Art. 44 each person has the right to receive information distributed for public use. It means that the Estonian citizens have the right, in accordance with the procedure established by law, to familiarise themselves with their data stored in state institutions and local self-government bodies, as well as in state and municipal archives. Under the law, this right may be limited for the purpose of protecting the rights and freedoms of others and the secrecy of a child's origin, as well as for the purpose of preventing a crime, detaining a criminal, or clarifying the truth during criminal proceedings.

As for the right of persons to freely express their ideas and views, this right may be limited by law for the purposes of protecting public order, moral principles, rights and freedoms, health, honour, and the good name of others. ${ }^{33}$ This right may be limited by law to civil servants and officials of local self-government bodies for the purpose of protecting state or trade secrets, which became known to them due to their official position or information obtained by them confidentially, as well as for the purpose of protecting the family and privacy of others and in the interests of justice.

In general, such restrictions are established exclusively by law in order to protect the rights and freedoms of others, in the interests of the defence of the state, in the event of a natural disaster, in order to stop the spread of infectious diseases, protect the natural environment, etc.

At the same time, the Constitution of Estonia provides for cases where under no circumstances fundamental rights and freedoms can be subject to restrictions. This norm is established in Art. 130 of the Basic Law of the State. Thus, the rights and freedoms established by Art. 8 (right to citizenship), Art. 12 (prohibition of discrimination due to national and racial affiliation, skin colour, gender, language, origin, religion, political or other beliefs), Art. 16 (right to life), the right to honour and a good name (Art. 17), the right to moral and material compensation in case of harm (Art. 25), the right to freedom of conscience and religion (Art. 40), and the right to nationality (Art. 49).

\section{THE SCANDINAVIAN MODEL OF EXCEPTIONS TO ENSURE CONSTITUTIONAL HUMAN RIGHTS}

The Scandinavian constitutions have their own model of exceptions to ensure constitutional human rights and freedoms. ${ }^{34}$ The Scandinavian countries are historically connected and are characterised by the democratic development features such as equality, sustainability, a welfare state, and a unicameral form of governance.

For example, the Constitution of Finland in regard to the protection of privacy states that in order to protect fundamental rights or disclose crimes, the law may provide for actions related to housing integrity. The law may also establish the necessary restrictions on the

33 A Albi, S Bardutzky, 'Revisiting the Role and Future of National Constitutions in European and Global Governance: Introduction to the Research Project' in A Albi, S Bardutzky (eds), National Constitutions in European and Global Governance: Democracy, Rights, the Rule of Law (TMC Asser Press 2019) <https://doi.org/10.1007/978-94-6265-273-6_1> accessed 24 June 2021.

34 M Klamberg, 'International Human Rights Law and States of Emergency' in D Rogers (ed), Human Rights in War. International Human Rights (Springer 2021) <https://doi.org/10.1007/978-981-155202-1_6-1> accessed 24 June 2021. 
observance of secrecy of information in the investigation of crimes that encroaches on the safety of the individual, society, or the inviolability of housing, in court proceedings, and control over security, as well as during imprisonment. ${ }^{35}$

Restrictions on constitutional rights also apply to the right to freedom of speech (para. 12).

Para. 23 of the Basic Law of Finland establishes that during a state of emergency, fundamental rights may be temporarily restricted by law or resolution of the State Council, adopted on the basis of powers enshrined by law for a special reason and clearly limited in their field of application, as necessary during an armed attack on Finland or during another kind of state of emergency that seriously threatens the security of the nation and is enshrined in law. At the same time, the restrictions must meet international human rights requirements, which Finland is obliged to comply with. However, the law should enshrine grounds for temporary restrictions. ${ }^{36}$

Resolutions of the State Council related to temporary restrictions should be immediately sent to the Parliament for consideration. Parliament can decide on the validity of resolutions. There are no other provisions regulating the introduction by the state of restrictions stipulated by the Constitution of the country.

As for the Constitutions of Norway and Denmark, the texts of both documents do not refer to restrictions on human rights of both political and economic nature.

\section{CONCLUSION}

The overwhelming majority of ECHR Member States implement the provisions of the Convention regarding the application of restrictions on rights and freedoms in their own national legal systems in various ways.

The scope and types of constitutional restrictions depend on the peculiarities of the legal traditions of each individual state.

The specifics of constitutional restrictions depend to a large extent on the European region in which one or another country is located. While in the countries of Continental and Eastern Europe, the constitutional restrictions of human rights are defined quite clearly with the establishment of the legal scope of such restrictions, in particular, during the period of martial law, exceptional status, as well as in the period of natural disaster, in the constitutions of the Baltic countries constitutional restrictions are distinguished depending on the political, economic or social nature of human rights.

A common feature of all constitutional restrictions on human rights and freedoms is that their application is due to objective circumstances and is necessary for a democratic society and under no circumstances should distort the essence of human rights and freedoms that fall under such restrictions.

35 Constitution of Finland, 11 June $1999<$ https://oikeusministerio.fi/en/constitution-of-finland $>$ accessed 20 May 2021.

36 T Ojanen, J Salminen, 'Finland: European Integration and International Human Rights Treaties as Sources of Domestic Constitutional Change and Dynamism' in A Albi, S Bardutzky (eds), National Constitutions in European and Global Governance: Democracy, Rights, the Rule of Law (TMC Asser Press 2019) <https://doi.org/10.1007/978-94-6265-273-6_9> accessed 24 June 2021. 


\section{REFERENCES}

1. Albi A, Bardutzky S, 'Revisiting the Role and Future of National Constitutions in European and Global Governance: Introduction to the Research Project' in A Albi, S Bardutzky (eds), National Constitutions in European and Global Governance: Democracy, Rights, the Rule of Law (TMC Asser Press 2019) <https://doi.org/10.1007/978-94-6265-273-6_1> accessed 24 June 2021.

2. Arnold R, 'Anthropocentric Constitutionalism in the European Union: Some Reflections' in The European Union - What is Next? (Wolters Kluwer 2018) 112-13.

3. Basic Law for the Federal Republic of Germany of 23 May $1949<$ https://www.btgbestellservice.de/pdf/80201000.pdf.> accessed 20 May 2021.

4. Biernat S, Kawczyńska M, 'The Role of the Polish Constitution (Pre-2016): Development of a Liberal Democracy in the European and International Context' in A Albi, S Bardutzky (eds), National Constitutions in European and Global Governance: Democracy, Rights, the Rule of Law (TMC Asser Press 2019) <https://doi.org/10.1007/978-94-6265-273-6_16> accessed 24 June 2021.

5. Coliver S, 'Spycatcher - The Legal and Broader Significance of the European Court's Judgment' (1992) 142 Tolley's J Media L \& Prac < https://heinonline.org/HOL/LandingPage?handle=hein. journals/tojmedlp13\&div=8\&id=\&page $>$ accessed 20 May 2021.

6. Constitution of Finland, 11 June $1999<$ https://oikeusministerio.fi/en/constitution-offinland> accessed 20 May 2021.

7. Constitution of Montenegro, 25 October 2007 <https://www.wipo.int/edocs/lexdocs/laws/ en/me/me004en.pdf $>$ accessed 20 May 2021.

8. Constitution of Spain, 27 December $1978<$ https://www.constituteproject.org/constitution/ Spain_2011.pdf?lang=en> accessed 24 June 2021.

9. Constitution of the Czech Republic of 16 December 1992. <https://www.psp.cz/en/docs/ laws/1993/1.html > accessed 20 May 2021.

10. Constitution of the Republic of Croatia of 22 December $1990<$ https://www.usud.hr/sites/ default/files/dokumenti/The_consolidated_text_of_the_Constitution_of_the_Republic_ of_Croatia_as_of_15_January_2014.pdf> accessed 20 May 2021.

11. Constitution of the Republic of Estonia, 28 June $1992<$ https://www.constituteproject.org/ constitution/Estonia_2015.pdf?lang=en> accessed 20 May 2021.

12. Constitution of the Republic of Lithuania, 25 October $1992<$ https://e-seimas.Irs.It/portal/ legalAct/lt/TAD/TAIS.21892?jfwid=-wd7z8ivg5> accessed 20 May 2021.

13. Constitution of the Republic of Poland of 2 April $1997<$ https://www.sejm.gov.pl/prawo/ konst/angielski/kon1.htm> accessed 20 May 2021.

14. Council of Europe, Convention for the Protection of Human Rights and Fundamental Freedoms [1950] <https://www.echr.coe.int/documents/convention_eng.pdf> accessed 20 May 2021.

15. Ernits $M$ et al, 'The Constitution of Estonia: The Unexpected Challenges of Unlimited Primacy of EU Law' in A Albi, S Bardutzky (eds), National Constitutions in European and Global Governance: Democracy, Rights, the Rule of Law (TMC Asser Press 2019) <https:// doi.org/10.1007/978-94-6265-273-6_19> accessed 24 June 2021.

16. Franeta $\mathrm{D}$, 'Human Dignity in Montenegro' in $\mathrm{P}$ Becchi, $\mathrm{K}$ Mathis (eds), Handbook of Human Dignity in Europe (Springer 2019) <https://doi.org/10.1007/978-3-319-280820_29> accessed 24 June 2021. 
17. Goldner Lang I, Đurđević Z, Mataija M, 'The Constitution of Croatia in the Perspective of European and Global Governance' in A Albi, S Bardutzky (eds), National Constitutions in European and Global Governance: Democracy, Rights, the Rule of Law (TMC Asser Press 2019) <https://doi.org/10.1007/978-94-6265-273-6_24> accessed 24 June 2021.

18. Human Rights Act [1998] <www.legislation.gov.uk/ukpga/1998/42> accessed 20 May 2021.

19. International Covenant on Civil and Political Rights [1966] <https://www.ohchr.org/en/ professionalinterest/pages/ccpr.aspx> accessed 20 May 2021.

20. Izarova I, Kravtsov S, 'About the Special Issue on the Occasion of the 70th Anniversary of the European Convention on Human Rights' 2021 1(9) Access to Justice in Eastern Europe 5-7.

21. Jarukaitis I, Švedas G, 'The Constitutional Experience of Lithuania in the Context of European and Global Governance Challenges' in A Albi, S Bardutzky (eds), National Constitutions in European and Global Governance: Democracy, Rights, the Rule of Law (TMC Asser Press 2019) <https://doi.org/10.1007/978-94-6265-273-6_21> accessed 24 June 2021.

22. Klamberg $M$, 'International Human Rights Law and States of Emergency' in D Rogers (ed), Human Rights in War. International Human Rights (Springer 2021) <https://doi. org/10.1007/978-981-15-5202-1_6-1> accessed 24 June 2021.

23. Kostadinov B, 'Human Dignity in Croatia' in P Becchi, K Mathis (eds), Handbook of Human Dignity in Europe (Springer 2018) <https://doi.org/10.1007/978-3-319-27830-8_7-1> accessed 24 June 2021.

24. Lachmayer K, 'The Constitution of Austria in International Constitutional Networks: Pluralism, Dialogues and Diversity' in A Albi, S Bardutzky (eds), National Constitutions in European and Global Governance: Democracy, Rights, the Rule of Law (TMC Asser Press 2019) <https://doi.org/10.1007/978-94-6265-273-6_27> accessed 24 June 2021.

25. Mohammad N, Hasan SM, 'Human Rights' in D Crowther, S Seifi (eds), The Palgrave Handbook of Corporate Social Responsibility (Palgrave Macmillan 2020) <https://doi. org/10.1007/978-3-030-22438-7_22-1> accessed 24 June 2021.

26. Muraviov V, Mushak N, 'Legal Issues of the Implementation of the Convention for the protection of Human Rights and Fundamental Freedoms 1950 in Ukraine' (2021) 1 (9) Access to Justice in Eastern Europe 11-22.

27. Muraviov M, Mushak N, 'Judicial Control of Public Power as Legal Instrument for Protection of Human Rights and Fundamental Freedoms in Ukraine' in Rule of Law, Human Rights and Judicial Control of Power (Springer 2017).

28. Mussig U, 'A New Order of the Ages. Normativity and Precedence' in U Mussig (ed), Reconsidering Constitutional Formation II Decisive Constitutional Normativity. Studies in the History of Law and Justice, vol 12 (Springer 2018) <https://doi.org/10.1007/978-3319-73037-0_1> accessed 24 June 2021.

29. Ojanen T, Salminen J, 'Finland: European Integration and International Human Rights Treaties as Sources of Domestic Constitutional Change and Dynamism' in A Albi, S Bardutzky (eds), National Constitutions in European and Global Governance: Democracy, Rights, the Rule of Law (TMC Asser Press 2019) <https://doi.org/10.1007/978-94-6265273-6_9> accessed 24 June 2021.

30. Savchyn M, 'Basic Constitutional Criteria for Limitation of Human Rights and Fundamental Freedoms' (2008) 2 (16) Elections and democracy 21-28.

31. Savchyn M, Current Trends in Constitutionalism in the Context of Globalization and Legal Pluralism: Monograph (RICK-U 2018) 123-124. 
32. Siskova N, 'European Union's Legal Instruments to Strengthen the Rule of Law? Their Actual Reflections and Future Prospects' in N Šišková (ed), The European Union - What Is Next? A Legal Analysis and the Political Visions on the Future of the Union (Wolters Kluwer 2018) 157-162.

33. Solanes Mullor J, Torres Pérez A, 'The Constitution of Spain: The Challenges for the Constitutional Order Under European and Global Governance' in A Albi, S Bardutzky (eds) National Constitutions in European and Global Governance: Democracy, Rights, the Rule of Law (TMC Asser Press 2019) <https://doi.org/10.1007/978-94-6265-273-6_12> accessed 24 June 2021.

34. Sydorets B, 'Restrictions on Human Rights (in the context of the ratio of the Constitution of Ukraine and the Convention for the Protection of Human Rights and Fundamental Freedoms)' (2012) 1 Elections and Democracy 63-69.

35. Universal Declaration of Human Rights [1948] <https://www.un.org/en/about-us/universaldeclaration-of-human-rights> accessed 20 May 2021.

36. Young AL, Birkinshaw P, Mitsilegas V, Christou TA, 'Europe's Gift to the United Kingdom's Unwritten Constitution - Juridification' in A Albi, S Bardutzky (eds) National Constitutions in European and Global Governance: Democracy, Rights, the Rule of Law (TMC. Asser Press 2019) <https://doi.org/10.1007/978-94-6265-273-6_3> accessed 24 June 2021. 